\title{
Oljen ja ruumenten käsittely suorakylvön yhteydessä
}

\author{
Hannu Mikkola \\ Maa- ja elintarviketalouden tutkimuskeskus, Maatalousteknologian tutkimus (VAKOLA) \\ Vakolantie 55,03400 Vihti, hannu.j.mikkola@mtt.fi
}

\section{Johdanto}

Maan pinnalla olevan oljen ja muun kasvinjätteen vaikutusta maan kosteuteen ja lämpötilaan, kasvitautien esiintymiseen sekä kasvien kasvuun ja satoon on tutkittu laajasti tutkittaessa vähennettyyn muokkaukseen perustuvia viljelymenetelmiä. Vähennetyllä maan muokkauksella tarkoitetaan yleensä kynnön korvaamista jollain sänkimuokkausmenetelmällä. Sänkimuokkaus kultivaattorilla onkin saavuttanut suosiota erityisesti savialueella, koska savimaan kyntäminen kuluttaa runsaasti koneita ja polttoainetta sekä vie paljon työaikaa. Työteknisten etujensa ohella sänkimuokkaukseen siirtyminen on jopa lisännyt sadon määrää jäykillä, poutivilla hiesu- ja savimailla (Pitkänen 1994). Vielä sänkimuokkausmenetelmääkin pelkistetympi kylvötapa on suorakylvö, jossa maata ei muokata lainkaan. Uusi kasvi kylvetään suoraan edeltävän kasvin sänkeen.

Vähennetyn muokkauksen tutkimukset on tehty ruutukokeina ja kasvinjäte on pyritty levittämään tasaisesti koko ruudun alalle, usein jopa käsin esim. Børresen (1999). Menettely on koeoloissa tarpeen, ettei kasvinjätteen epätasainen jakauma hämärrä tutkittavan käsittelyn vaikutusta. Liian vähälle huomiolle on kuitenkin jäänyt, että käytännön viljelyssä kasvinjäte jakautuu pellon pinnalle usein varsin epätasaisesti. Hultgreen (2000) toteaakin, että kasvinjätteen käsittely on suorakylvömenetelmän kriittinen osatekijä. Epäonnistuminen kasvinjätteen käsittelyssä voi olla syy seuraavan vuoden huonon satoon. Oljista ja ruumenista näyttäisi olevan haittaa erityisesti syysviljojen kylvössä, koska olki ei ehdi maatua lainkaan ennen kylvöä. Christian et al. (1999) totesivat olkisilpun vähentävän kolmanneksen syysvehnän satoa, kun sitä verrattiin poltettuun sänkeen suorakylvettyyn syysvehnään. Näissä kokeissa jyväsadot olivat suuria ja siten myös olkisatojen on täytynyt olivat suuria verrattuna suomalaisiin satoihin. Yhdeksän vuoden siemensadon keskiarvo vaihteli menetelmästä riippuen välillä 5400 $-8000 \mathrm{~kg} / \mathrm{ha}$.

Toisaalta Børresen'in (1999) tekemissä kevätviljan suorakylvötutkimuksissa niinkään suuri määrä olkea kuin $8600 \mathrm{~kg} / \mathrm{ha}$ ei vielä alentanut satoa. Børresen toteaa, että runsas olkimäärä voi olla hyödyllinen, jos seuraava kasvukausi on kuiva. Jos touko- kesäkuussa sen sijaan sataa normaalia enemmän, jo alle 3000 kilon olkimäärä voi alentaa satoa.

Kasvinjätteen määrä pellolla vaihtelee, koska kasvuston määrä pellolla vaihtelee ja korjuun yhteydessä olki ja ruumenet leviävät vain osalle työleveydestä. Puimurin seulaston leveys on 1/3 - 1/5 työleveydestä, jolloin ääritapauksessa yhdellä viidesosalla pellon pinta-alasta on pellon kaikki ruumenet. Olki leviää silppurista hieman leveämmälle kuin ruumenet, mutta pääosa siitäkin jää puintikaistan keskikohdalle. Kasvinjätteen epätasainen jakautuminen johtaa maan epätasaiseen kuivumiseen ja lämpenemiseen. Paksu olkikerros huonontaa orastumista tai estää sen kokonaan. Siksi kasvinjätteen tasaiseen jakautumiseen pitäisi kiinnittää huomiota erityisesti suorakylvön yhteydessä. Kaikki puinnin jälkeiset korjaavat toimet lisäävät kustannuksia ja huonontavat suorakylvön kilpailukykyä.

Tämän tutkimus on osa vuonna 2002 Maa- ja elintarviketalouden tutkimuskeskuksessa aloitettua Kevätviljan suorakylvö -nimistä tutkimusta ja yksi sen tavoitteista on esittää käytännön keinoja, joiden avulla kasvinjätteet saadaan levitettyä mahdollisimman tasaisesti jo puinnin yhteydessä. Koska toivottuun lopputulokseen ei aina päästä, tässä kerrotaan myös, mitä kasvinjätteelle voidaan tehdä, kun pellolla on olkikasoja puinnin jälkeen.

\section{Kasvinjätteen määrä}

Keväällä 2002 tehty mittaus kahdella peltolohkolla Vihdissä osoitti, että puimurin työkaistan keskellä oli noin 1,5-kertainen määrä kasvinjätettä verrattuna työkaistan reunoihin. Mittaus tehtiin keräämällä kaikki kasvinjäte $0,5 \mathrm{~m}^{2}: \mathrm{n}$ suuruisilta, sattumanvaraisesti valituilta kohdilta puintikaistojen keskeltä ja niiden välialueelta. Näytteet kuivattiin ilmakuiviksi ja punnittiin. Mittauksia ei tehty päistealueella eikä kohdissa, joissa puimuri oli syystä tai toisesta seissyt paikallaan. Mittauskohtia oli lohkolla A viisi ja lohkolla B kuusi. Lohkolla A oli viljelty edellisenä vuonna kevätvehnää ja lohkolla B ohraa. Tulokset on esitetty kuvassa 1. Koska ohran olkimäärä on pienempi kuin esimerkiksi kauran tai rukiin, ero kaistan keskikohdan ja reunojen välillä voi olla paljon mitattua suurempikin. 


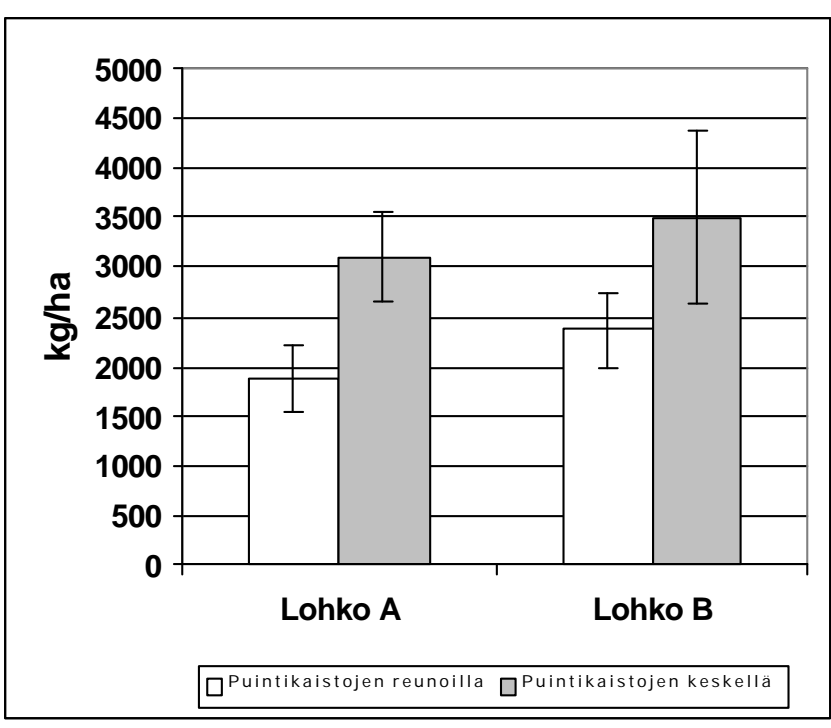

Kuva 1. Kasvinjätteen määrä ja sen keskihajonta kahdella koelohkolla Vihdissä keväällä 2002. Esikasvina oli lohkolla A kevätvehnä ja lohkolla B ohra.

\section{Leikkuupuimurin rakenne ja säädöt}

Puimurinvalmistajat ottavat nykyään entistä paremmin huomioon sen, että olki on silputtava hyvin ja että olki sekä ruumenet on kyettävä levittämään mahdollisimman tasaisesti koko pellon alalle. Joissakin uusissa puimurimalleissa ruumenet voidaan ohjata kulkemaan silppurin kautta. Käytössä on kuitenkin paljon vanhoja puimureita, joiden oljenlevittämiskykyä pitäisi parantaa. Silppurin vaihtaminen uudempaan ei yleensä kannata eikä myöskään suurten muutosten tekeminen vanhaan puimuriin.

Ensiksi kannattaa varmistaa, että silppurin kaikki terät ja vastaterät ovat paikallaan ja teräviä. Silppuri säädetään tekemään mahdollisimman lyhyttä silppua ja silpun ohjainpellit säädetään levittämään olki mahdollisimman hyvin. Helpoin rakenteellinen muutos on tehdä tai teettää uudet ohjainpellit, jotka ohjaavat silppua enemmän puintikaistan sivuille.

Silppurin pyörimisnopeutta ei pidä turvallisuussyistä lähteä nostamaan ainakaan ilman valmistajan lupaa. Samoin ei pidä kääntää oljen hajotinsuppiloa vaakasuoraan tai poistaa sitä kokonaan, koska silloin silppuriin joutunut kivi tai metalliesine lentää sieltä suoraan taaksepäin kiväärin luodin nopeudella.

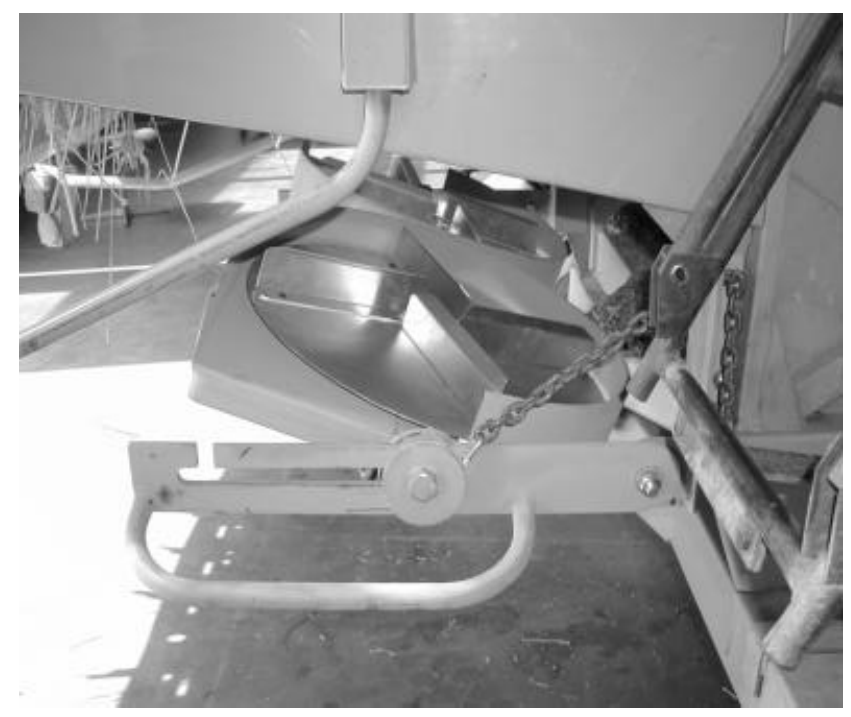

Kuva 2. MTT/Vakolassa rakennettu hydraulikäyttöinen ruumenten levitin.

käännöstä. Toinen mahdollisuus on puida ympyrää, jolloin lohkon nurkkiin jää joka kierroksella puimattomat kaistaleet. Ne puidaan lopuksi ristiin ajaen. Kolmas vaihtoehto on avata nurkkakohdat heti puintia aloitettaessa, jolloin ensimmäiset kierrokset voidaan ajaa lohkoa ympäri. Kun päisteet on puitu, puintia jatketaan reunasta edestakaisin ajaen. Kulmien avaaminen ei välttämättä osu täysin kohdalleen, mutta se ei haittaa esitetyn ajotekniikan käyttöä. Ajotekniikan valintaan vaikuttaa tietenkin lohkon koko ja muoto sekä mahdollisen laon suunta, joten mitään yksittäistä tekniikkaa ei voida noudattaa aina ja joka paikassa. Sopivin ajotekniikka valitaan tilanteen mukaan ottaen huomioon myös puinnin joutuminen. Puitaessa kannattaa jättää pitkä sänki. Tällöin olkisilppua tulee maan pintaan mahdollisimman vähän. Pitkä sänki ei yleensä haittaa kylvöä. 


\section{Kasvinjätteen levittäminen puinnin jälkeen}

Hyvästä ajotekniikasta huolimatta pellolle voi jäädä olkikasoja tai olkea on kerta kaikkiaan niin paljon, että siitä tulee paksu kerros joka paikkaan. On olemassa keinoja, joilla kylvön onnistuminen voidaan varmistaa olkikasoista huolimatta. Olkikasat voidaan levittää kelasilppurilla, josta on poistettu puhallustorvi. Kasat voidaan levittää myös kesantosilppurilla tai pyöröpöyhimellä. Polttaminen on yksi vaihtoehto, mutta kaikkea olkea ja sänkeä ei kannata polttaa, koska kasvinjätteestä on myös hyötyä. Olkikate hidastaa maan kuivumista poutakausina ja kasvinjäte on lierojen ravintovarasto.

Jos olkea on runsaasti koko pellon alalla ja pelto kylvetään keväällä, kevyt sänkimuokkaus syksyllä 5-10 sentin syvyyteen nopeuttaa oljen lahoamista. Suorakylvöön siirtyvä tila ei siis pääse eroon täysin muokkauskoneista, mutta muokkauskustannuksia voidaan oleellisesti alentaa. Jos oljille on käyttöä tai markkinoita ne voidaan myös korjata pois. Kaikki puinnin jälkeen tehdyt toimenpiteet $\mathbf{I}-$ säävät kuitenkin kustannuksia ja siksi kannattaa pyrkiä levittämään oljet ja ruumenet jo puinnin yhteydessä.

Erikseen on syytä mainita, että sänkimuokkaus ennen syyskylvöä johtaa useimmiten kylvökoneen tukkeutumiseen. Suorakylvökoneen lautas- tai kiekkovantaat eivät saa riittävästi vastusta muokatusta maasta eivätkä pyöri kunnolla. Jos syksyllä kylvettävällä lohkolla on runsaasti olkea, vaihtoehtoina on kerätä oljet pois, polttaa ne tai kyntää ja muokata pelto perinteisesti.

\section{Johtopäätökset ja suositukset}

Suorakylvettävän pellon kylvöalusta tehdään leikkuupuimurilla. Olki ja ruumenet pitäisi siksi saada levitettyä mahdollisimman tasaisesti koko pellon alalle jo puinnin yhteydessä. Oljen levittäminen ja silppuaminen jälkikäteen lisää työtä ja kustannuksia. Uutta puimuria hankittaessa kannattaa suosia malleja, joissa on tehokas silppuri ja mahdollisuus saada olkisilppu leviämään koko työleveydelle. On eduksi, jos ruumenet voidaan ohjata silppurin kautta tai jos puimuriin on saatavissa erillinen ruumenten levitin.

Vanhojen puimureiden silppureiden kunto tarkastetaan ja ne säädetään tekemään mahdollisimman lyhyttä silppua. Silpun ohjainpellit säädetään levittämään silppu mahdollisimman leveälle. Kannattaa myös kokeilla, voidaanko ohjainpellit muotoilla uudelleen siten, että entistä suurempi osa silpusta leviää työleveyden reunoille. MTT/Vakolassa on rakennettu ruumenten levitin, jolla saadaan myös vanha puimuri levittämään ruumenet koko työleveydelle. Levittimen rakentamista kannattaa harkita ensisijaisesti suuriin puimureihin, joiden työleveys on yli $4 \mathrm{~m}$.

Puitaessa tulee suosia ajotekniikkaa, jossa puimuria ei pysäytetä, ennen kuin oljen tulo silppurista on loppunut. On suositeltavampaa tehdä päisteessä silmukkakäännös kuin peruutuskäännös. Lohkon nurkat voidaan puida pyöreiksi ja jäljelle jääneet kaistat puidaan lopuksi ajaen pellon nurkasta nurkkaan. Yksi suositeltava tapa on puida nurkat auki heti aluksi, jonka jälkeen puintia voidaan jatkaa keskeytyksettä. Kannattaa jättää pitkä sänki, koska silloin maan pinnalle tulee olkisilppua mahdollisimman vähän.

Jos olkea on kaikesta huolimatta puinnin jälkeen kasoina tai paksuina karheina, niitä voidaan levittää kelasilppurilla, sänkimurskaimella tai pyöröpöyhimellä. Oljen voi myös kerätä pois. Polttamista on syytä välttää, koska se tuhoaa lierojen ravintovaraston, poistaa oljen katevaikutuksen sekä vähentää orgaanisen aineksen kertymistä pellon pintaan.

\section{Kirjallisuus}

Børresen, T. 1999. The effect of straw management and reduced tillage on soil properties and crop yields of spring-sown cereals on two loam soils in Norway. Soil \& Tillage Res. 51: 91 - 102.

Christian, D.G., Bacon, E,T,G., Brockie, D., Glen, D., Cutteridge, R.J., \& Jenkyn, J.F. 1999. Interactions of straw disposal methods and and direct drilling or cultivations on winter wheat (Triticum aestivum) grown on a clay soil. J. Agric. Engng Res. 73: 297 - 309.

Hultgreen, G. 2000. Residue management. In: Leduc, P.J. (ed.). Direct seeding manual. Prairie Agricultural Machinery Institute. p. 19-26.

Pitkänen, J. 1994. A long-term comparison of ploughing and shallow tillage on the yield of spring cereals in Finland. In: Proceedings of the 13th Conference of International Soil Tillage Research Organization. p. 709-715. 